\title{
Evaluation of glass-grade silica sand resources, Nellore District, Andhra Pradesh, India using GIS.
}

\author{
P. Rameshchandra Phani \\ Cyient Limited, Plot No.11, Software Units Layout 2, Infocity, Madhapur, Hyderabad 500 081, India.
}

\begin{abstract}
In India silica sands are produced from loosely consolidated sands and weakly cemented sandstones ranging from Recent to Pre-Cambrian in age. In this paper an attempt has been made to estimate the silica sand resources, belonging to Holocene age, located at about 20km east of Gudur town, Nellore District, Andhra Pradesh. Silica sand occurs in this region as dunes of marine origin covering an area of $110 \mathrm{Sq} . \mathrm{Km}$. Ayyavaraiah et al (2013) reported that production and reserves estimated and declared by State Mines \& Geology and Indian Bureau of Mines do not match and a difference exists. Hence an attempt has been made to estimate the actual reserves of silica sand deposits of this area using Google Earth imagery, GIS and field auger hole data. The total area that was mined already is about 9.538 Sq.Km. amounting to 117 Million Tons of silica sand that was produced in past 10-15 years with 59 Million Tons still to be excavated in the currently active mines. By surface area mapping using GIS, the prospective areas for further exploration and exploitation are suggested, giving rise to total prospective reserves of silica sand of 849 Million Tons.
\end{abstract}

Keywords: Glass-grade silica sand, Resource evaluation, GIS, Gudur, Nellore Dt., Andhra Pradesh.

\section{Introduction}

Silica sand forms the major ingredient among natural raw materials required for glass making and it is also used in foundry, ferro-silica alloy and cement industries besides being used in many other industries like ceramic, fertilizer, abrasives, chemical, coal washery, electrode, paint, rubber, textile, water filtration, construction etc. The natural silica sand is preferred in glass industries, but in cases when silica deposits are located far away, crushed quartz is used. Silica sand deposits are widely spread over a span of $110 \mathrm{Sq} . \mathrm{Km}$ area east of Gudur town in Nellore district of Andhra Pradesh (Fig.1). Present paper deals with estimation of silica sand reserves of Nellore Dt., using Google Earth imagery, digital mapping interpretations, GIS in corroboration with field data. These surface deposits occur as beach dunes, that can easily be excavated and being utilised by various mineral based industries situated in Chennai, Bangalore, Hyderabad etc. As per reports of Indian Bureau of Mines, the silica sand deposits of the study area can be compared with those of Langholme sand mine in Humberside of United Kingdom (IBM, 1993). As per government reports, number of mining leases are 74 covering an area of 1202.51 Hectares (IBM, 2012) in Nellore district.

From the present study it is inferred that the study area, forms a more or less flat beach plain, was submerged under seawater sometime in the Pleistocene to Holocene Period, characterised by long spells of global cooling or glaciation alternating with global warming (Ayyavaraiah et al, 2013). As per Geological Survey of India, District Resource Maps, these deposits belong to marine to fluvio-marine origin containing tidal flat $(\mathrm{Qmb})$ and deltaic $(\mathrm{Qfm})$ deposits with unconsolidated sand, silt and clay sediments in varying amounts with variable effective porosity to carry fresh to saline groundwater in varying amounts and dune sands have an aeolian origin (Fig.1). Previous studies related to micropalaeontology, sedimentation history, neotectonics, along the coastal tract of this part of the country indicated that there was once rise of sea level due to global warming leading to transgression (submergence) of some $20 \mathrm{~km}$ wide coastal land east of Gudur town under the sea. This was followed by lowering of sea level owing to global cooling leading to regression of land leading to exposure of land, to the present position with deposition of coastal sediments and dune sands of aeolian origin. The mineral grains of dunes under intense wind action, reworked during a number of sedimentary cycles, are almost wholly composed of quartz with remarkable uniformity in grain size and high roundness. These dune sand deposits occur in the study area as crescent-shaped deposit occurring on east coast measuring around 17 $\mathrm{km}$ in length, $2.5 \mathrm{~km}$ in breadth, $42.5 \mathrm{Km}^{2}$ in area and $10 \mathrm{~m}$ in depth in the study area (Fig. 1). No information could be gathered about the total vertical thickness of sand cover with respect to good quality sand and no information about basement depth is given in the available literature. Although in northern part close to Krishnapatnam port, some deep drilling was carried out by private contractor companies, the litho-logging information is not available. It is to be noted that no other area in Andhra Pradesh and/or recently separated Telangana state carries glass-grade silica sand deposits than Nellore district in vast quantities, that can be readily excavated. Deposits in Urvakal area of Kurnool district are crushed product of siliceous quartzite of Kurnool Group rocks of Proterozoic age. 


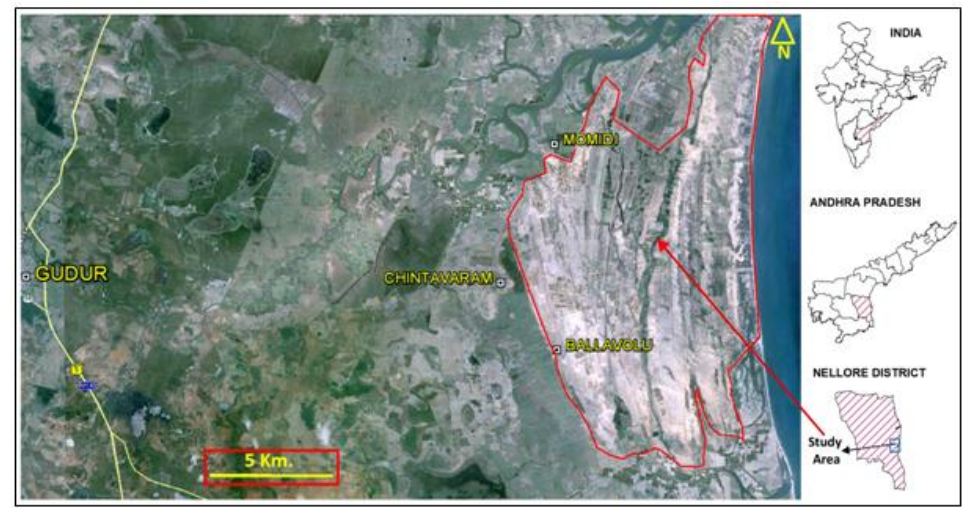

Figure 1. Location and Google Earth image showing study area, $20 \mathrm{~km}$ east of Gudur.

\subsection{Glass-grade sand specifications}

The glass industry is the most important consumer of silica sand, although the mineral is consumed in many other sectors of the economy. Geochemical and granulometric industry specifications prescribed by Indian Bureau of Standards for silica sand for glass making is given in Table $1 \& 2$. Grades other than Table $1 \& 2$ are low in purity. However these specifications vary for each factory depending upon the plant size, capacity, machinery and product requirements. Typically the grade is determined by the iron content of the sand in the ground. Very low iron sands naturally are white or off-white.

Table 1. Indian Standard specifications for glass making sands- $2^{\text {nd }}$ Revision (IS 488: 1980)

\begin{tabular}{|c|c|c|c|c|}
\hline \multirow{2}{*}{$\begin{array}{c}\text { Characteristic } \\
(\% \text { by mass) }\end{array}$} & $\begin{array}{c}\text { Special } \\
\text { Grade }\end{array}$ & Grade-I & Grade-II & Grade-III \\
\cline { 2 - 5 } & 0.5 & 0.5 & 0.5 & 0.5 \\
\hline $\mathrm{LOI}^{\mathrm{Nax} .}$ & 99.0 & 98.5 & 98.0 & 97.0 \\
\hline $\mathrm{SiO}_{2}$ (Min.) & 0.02 & 0.04 & 0.06 & 0.10 \\
\hline $\mathrm{Fe}_{2} \mathrm{O}_{3}$ (Max.) & $*$ & $*$ & $*$ & 1.5 \\
\hline $\mathrm{Al}_{2} \mathrm{O}_{3}$ (Max.) & 0.1 & 0.1 & 0.1 & $*$ \\
\hline $\mathrm{TiO}_{2}(\mathrm{Max})$. & \multicolumn{5}{|c|}{ To pass the test } \\
\hline $\mathrm{MnO}, \mathrm{CuO}, \mathrm{Cr}_{2} \mathrm{O}_{3}$ & \multicolumn{5}{|c|}{} \\
\hline
\end{tabular}

*Shall be as agreed to between the purchaser and supplier.

Special grade refers to raw material for glass making. Grade I, for the manufacture of container glass, etc. Grade II, for the manufacture of container glass with slight tint, and Grade III, for coloured glasses.

Table 2. Granulometric specifications for glass grade sand.

\begin{tabular}{|c|c|}
\hline Grain-size & \% by weight \\
\hline$+1 \mathrm{~mm}$ sieve & Nil \\
\hline+600 micron IS sieve (max.) & 1.0 \\
\hline-600 micron but + 300 micron IS sieve (max.) & 50.0 \\
\hline 125 micron IS sieve (max.) & 5.0 \\
\hline
\end{tabular}

The physical specifications of silica sand specifies that silica sand shall be fairly free from contamination like clay material, pebbles and other extraneous matter. The sand should not contain more than 4\% moisture. The study area in in Nellore district is endowed with varied grades and qualities of silica sand deposits that suit the above criteria, w.r.t. industry requirements. (IS 488: 1980).

\section{Study Area \& Methodology}

The Nellore silica sand deposits are confined exclusively to the coastal zone between the Upputeru and Swarnamukhi rivers in Nellore district between North Latitudes $14^{\circ} 02^{\prime}$ and $14^{\circ} 10^{\prime}$ and East Longitudes $79^{\circ} 51^{\prime}$ and $80^{\circ} 09^{\prime}$ in the $1: 50 \mathrm{~K}$ Survey of India restricted topographic maps $57 \mathrm{~N} / 16$ and $66 \mathrm{C} / 1$. The three major silica sand mining locations in the study area are shown in Fig.1. Google Earth imagery was captured, stitched to form a mosaic and georeferenced before various image elements were digitally mapped using ESRI ArcGIS version 10.1. Based on tone, texture and local knowledge sand deposit boundaries, strand lines and various land use patterns were delineated and thus surface area mapping was carried out. Prospective zones with and without vegetation cover were delineated and resources for both of these categories were calculated by considering parameters like volume and specific gravity. A general thickness of 8 meters is considered to calculate the resources. 
Features thus mapped were limitedly ground-checked. Granulometric and geochemical data covering entire area, which were collected by local mining agencies was used in this study. Sampling was done using manual auger of 6 inch diameter to a depth minimum 1.5 to 4 meters. Auger holes were placed in plain lands which are devoid of dunes. The material yielded by auger-holes was composited to form four bulk samples with respect to Momidi, Eruru, Chintavaram and Ballavolu areas. These composite samples were analyzed for granulometry and geochemistry. Thickness of different layers was compiled from auger test hole logs to understand the depth and thickness of strata in areas marked as prospective zones, profiles were plotted and thus resources were estimated.

\subsection{General}

\section{Discussion}

Silica sand mines can be identified very easily in the high-resolution Google Earth open web-source, from their characteristic grid pattern with alternating bands of sand (white) and the exposed groundwater in mined portions (black) exhibiting linear scrapings (Fig.2). In Google Earth, recently excavated or active mines appear in lighter tone due to recent water table upwelling whereas deeper/idle mines that have touched organic rich layer appear in darker one. An example from Momidi area referring to this aspect showing image signature of active and idle mines is shown in Fig.2. Some photographs of mines where in water table is punctured at a very shallow depth of 1 meter and heaps of sieved sand are shown in Fig. 3. Various features related to mining activity delineated from the large scale Google Earth image in the study area (Fig. 4), are listed in Table 3. Resource area is interpreted visibly by studying the image elements. The methods of mining of silica sand adopted however are such that it is difficult to mine once the water table is reached. Because of high groundwater yield, the water table cannot be also lowered by pumping (Ayyavaraiah et al, 2013).

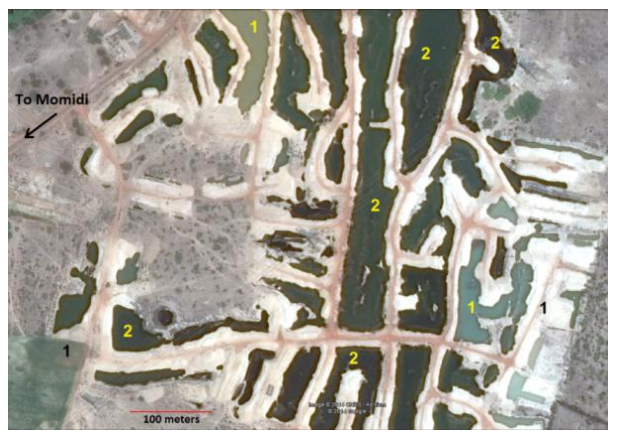

Figure.2. Google Earth image showing deeper/idle mines (1) and active/recent mines (2) of Momidi area. Tonal change between old and new excavation can be noticed.





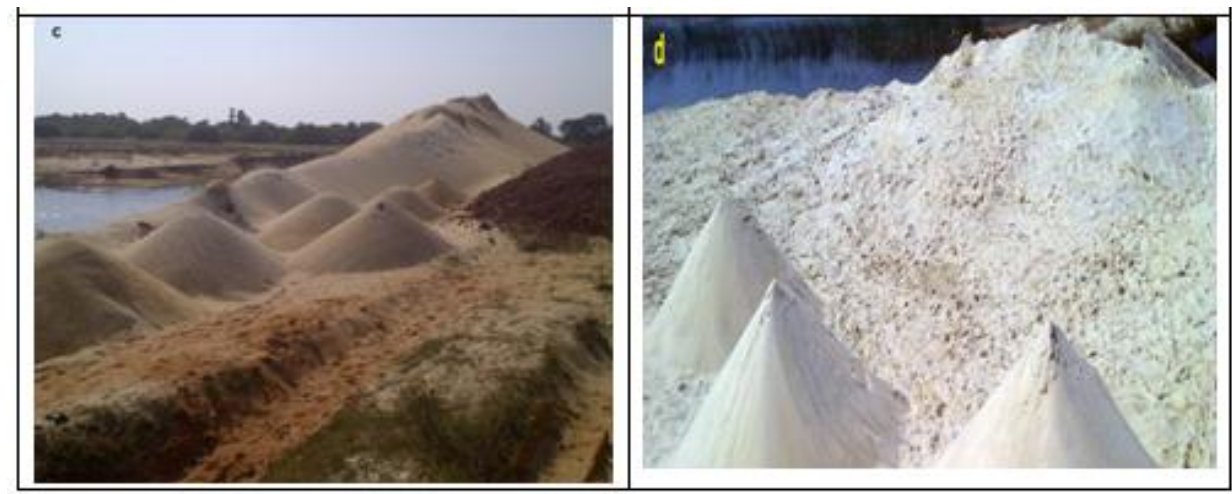

Fig. 3 Field photographs showing silica sand. a) active/ recent mine (Source: Ayyavaraiah et al) b) groundwater perched to surface after excavation, dunes in back drop c) sieved sand in heaps d) heaps of glass grade white sand. (Source: D.S. Sands).

Manual auger sampling revealed that most of the silica sand in this area occurs to a depth of $10 \mathrm{~m}$ containing sand layers of different qualities, while the water table lies at a depth of 1-2 meters from the ground level. Within the $10 \mathrm{~m}$ thick sand blanket, different layers of sand occur. The generalised stratification revealed in EW sections with reference to localities Momidi, Chintavaram and Ballavolu is shown in Fig.5. The thickness of different sand layers is more or less equal throughout the area of the crescent.

The top veneer of 0 to 0.3 meters contains predominantly fine sand, silt and other drifted material with less quantities of useful sand; it is often mixed with dry wind-blown fine sand. The wet sand is coarser and less in iron content. Generalised thickness of sand layers visualised through auger sections is shown in Table 3.

The granulometry of Momidi and Chintavaram and geochemistry of washed composite samples of main mining localities of Momidi, Eruru, Chintavaram and Ballavolu are shown in Figure $6 \&$ Table 4. From the granulometric analysis it is observed that these Holocene coastal sediments consist of sand, silt, clay and shell fragments in varying amounts with variable effective porosity to carry fresh to saline groundwater. Also

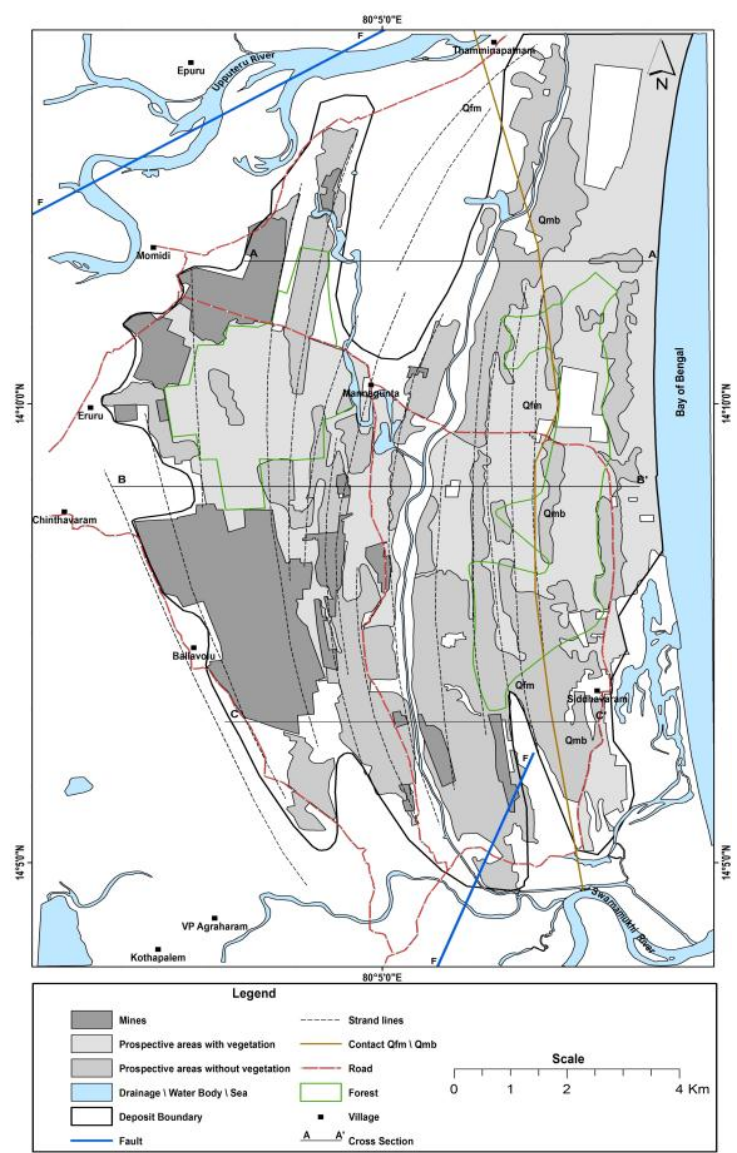

Figure. 4. Features interpreted from Google Earth image 


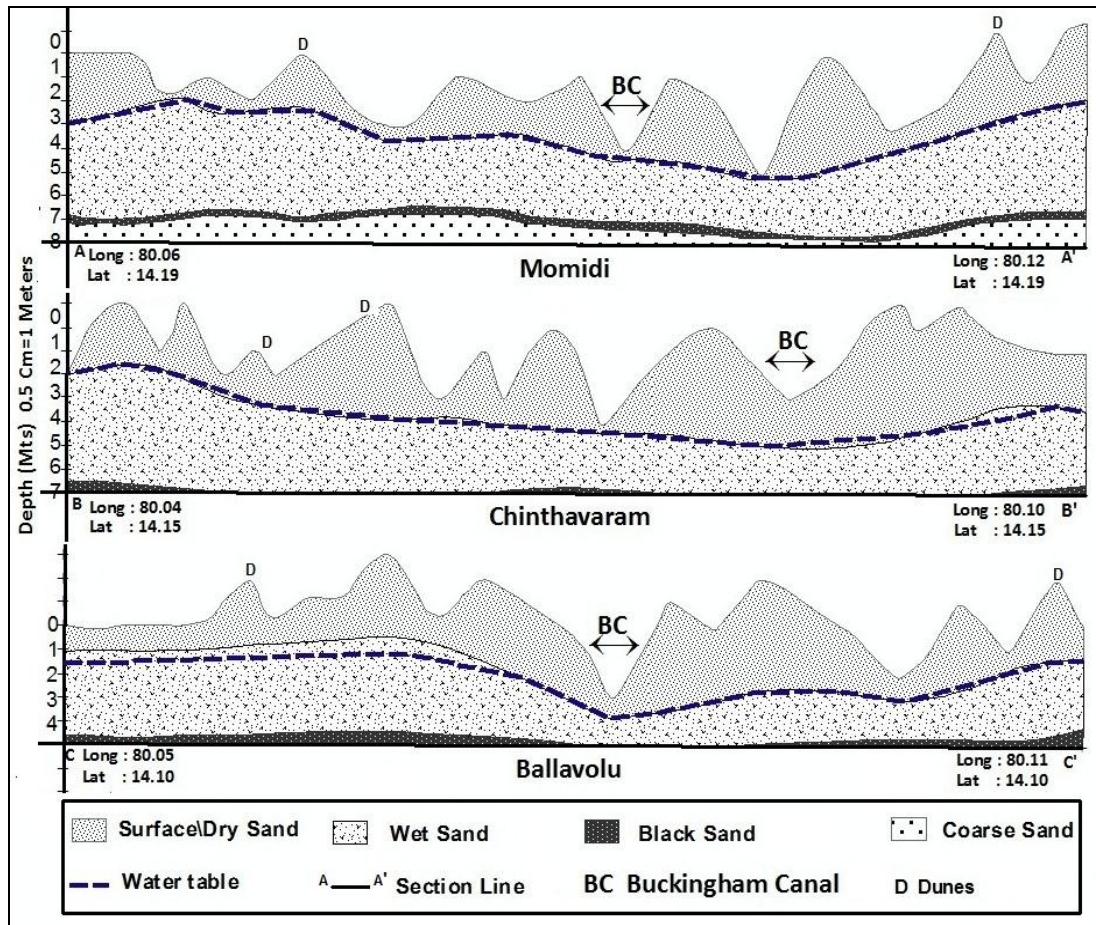

Figure 5. EW Profiles showing thickness of different layers.

Table 3. Generalised sand layer sequence in the study area.

\begin{tabular}{|c|c|c|c|c|c|}
\hline $\begin{array}{c}\text { Thickness range } \\
\text { average (meters) }\end{array}$ & Layer & $\begin{array}{c}\text { Organic } \\
\text { matter\% }\end{array}$ & Clay\% & Silt\% & Sand\% \\
\hline $0-0.3$ & Surface sand & 5 & 15 & 20 & 60 \\
\hline $0.3-1.2$ & Dry sand & 5 & 5 & 10 & 85 \\
\hline \multicolumn{5}{|c|}{$1-2$ meters Water table } \\
\hline $1.2-6.1$ & Wet sand & - & 10 & 10 & 90 \\
\hline 6.1 to 6.5 & Black sand & 20 & 10 & 10 & 60 \\
\hline 6.5 to 21 & Coarse sand & - & 10 & 5 & 90 \\
\hline
\end{tabular}

The granulometry of Momidi and Chintavaram and geochemistry of washed composite samples of main mining localities of Momidi, Eruru, Chintavaram and Ballavolu are shown in Figure 6 \& Table 4. From the granulometric analysis it is observed that these Holocene coastal sediments consist of sand, silt, clay and shell fragments in varying amounts with variable effective porosity to carry fresh to saline groundwater.
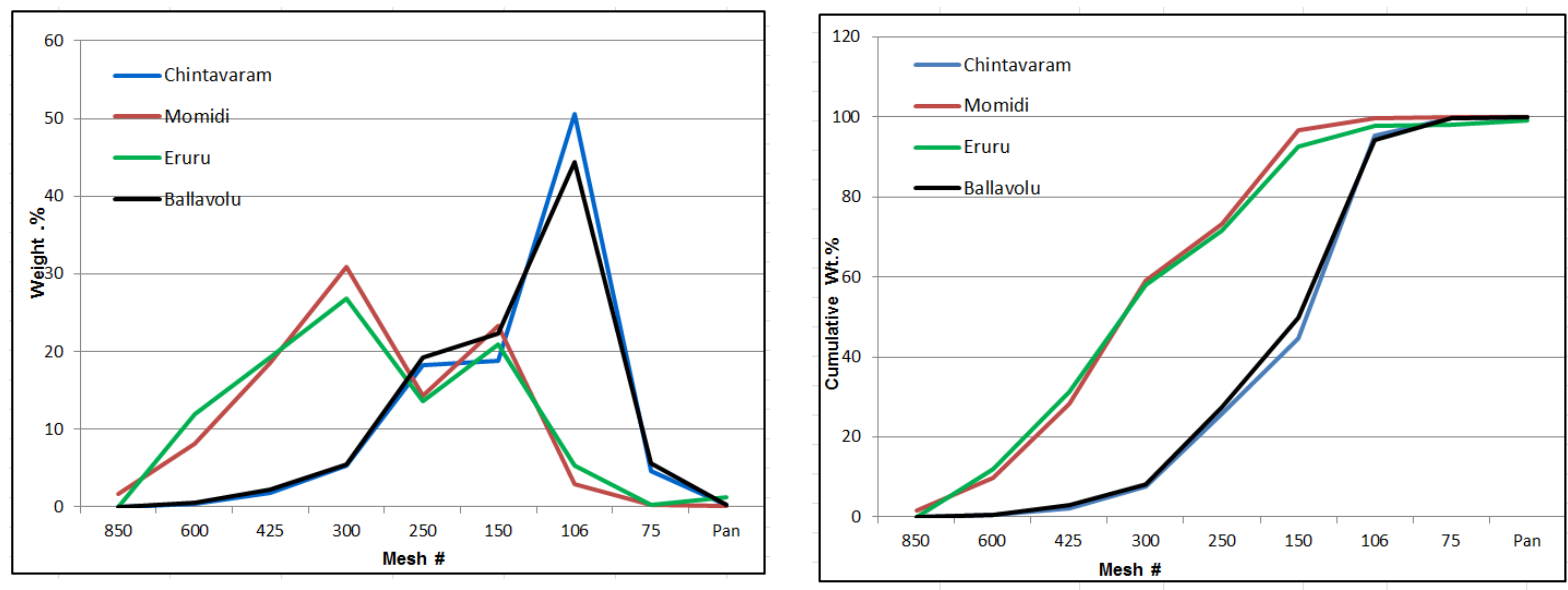

Fig. 6. Granulometry (Mesh size Vs. Weight\% and Cumulative weight \%) of Momidi \& Chintavaram bulk samples. 
Table 4. General grain-size and geochemical composition.

\begin{tabular}{|c|c|c|c|c|c|c|}
\hline \multirow[t]{2}{*}{ Area } & \multirow{2}{*}{$\begin{array}{c}\text { Grain-size\% } \\
(-600 \text { to }+300 \mu)\end{array}$} & \multicolumn{2}{|c|}{$\mathrm{Fe}_{2} \mathrm{O}_{3} \%$} & \multirow{2}{*}{$\mathrm{TiO}_{2} \%$} & \multirow{2}{*}{$\mathbf{A l}_{2} \mathbf{O}_{3} \%$} & \multirow{2}{*}{$\mathbf{K}_{2} \mathbf{O} \%$} \\
\hline & & Min. & Max. & & & \\
\hline Momidi & 15 & 0.08 & 0.22 & 0.039 & 1.5 & 0.86 \\
\hline Eruru & 15 & 0.07 & 0.25 & 0.035 & 1.65 & 0.8 \\
\hline Chintavaram & 20 & 0.06 & 0.13 & 0.04 & 1.56 & 0.77 \\
\hline Ballavolu & 15 & 0.02 & 0.08 & 0.02 & 1.25 & 0.64 \\
\hline
\end{tabular}

$\mathrm{D}_{50}$, the median diameter or the value of the particle diameter at $50 \%$ in the cumulative distribution is calculated to be 126, 130320 and 360 for Momidi Eruru, Chintavaram and Ballavolu sands respectively. The mineral grains of dunes under intense wind action, reworked during a number of sedimentary cycles, are almost wholly composed of quartz with remarkable uniformity in grain size and high roundness. High grain roundedness of these sediments indicates longer distances of transportation and high energy sedimentation environment. Deeper layers beyond the black sand layer are observed to be coarse-grained and rich in $\mathrm{Fe}_{2} \mathrm{O}_{3}$ (1000-1500 ppm). Presence of fresh feldspar indicates low or negligible chemical alteration. Heavy mineral assemblages commonly include magnetite, ochreous haematite, ilmenite, kyanite, zircon tourmaline and chromite which indicate a metamorphic and igneous provenance comprising Archaean rock types like granite, khondalite, charnockite, dolerite and schists.

\section{2 Production}

In India, Gujarat was the leading producer, accounted for $41 \%$ of the total production during the year2011-2012, followed by Andhra Pradesh (29\%), Rajasthan (16\%), Maharashtra (7\%), Jharkhand (3\%), Kerala and Uttar Pradesh (1\% each) with remaining $2 \%$ production by Karnataka and Tamil Nadu. Although silica sand mines exist in parts of Guntur and Prakasam districts, Nellore silica sand accounts for around $99 \%$ of the entire state's production. According to Statistical profiles of minerals, in Nellore district silica sand supply from Momidi of the study area is recorded as the highest (IBM, 2013).

According to Ayyavaraiah et al (2013) the details of production reported by Indian Bureau of Mines and State Mines \& Geology department are not identical. The year-wise production of Nellore silica sand from 2000-01 to 2010-11 as collected at the Office of the Assistant Director of Mines Geology, Nellore ranges from 0.39 million tonnes in 2001-02 to 1.91 million tonnes in 2010-11 with a mean of 0.97 thousand tonnes. In contrast, the production of Nellore silica sand as reported by the Indian Bureau of Mines is consistently lower. For example, IBM (2011b) reports production of Nellore silica sand in 2009-10 to be 948 thousand tonnes as against 1.5 million tonnes reported by the State Department of Mines and Geology. Thus the figure arrived at by the IBM is $63 \%$ of the figure of the State Department of Mines and Minerals. In the interest of people to have faith in the data furnished by the Government Departments, there is need for the sister Government Departments to report data of definitive nature without discrepancies (Ayyavaraiah et al, 2013).

As per the report of the Sub-Group on $12^{\text {th }}$ Plan, Planning Commission of India, the domestic demand of quartz and silica minerals is estimated at 3.15 million tonnes by 2011-12 and at 4.85 million tonnes by 201617 at $9 \%$ growth rate. Average production percentage of silica sand solely from Nellore district amounts to about 36.72 out of total production in India (Table 5), from 2008 to 2012.

Table 5. Production of silica sand from 2008 to 2012 (IBM, 2012).

As per government reports, decennial production of silica sand and sand from other sources in the country increased to 43,34,925 Tonnes (IBM, 2012).

\begin{tabular}{|c|c|c|c|c|}
\hline & $2008-2009$ & $2009-2010$ & $2010-2011$ & $2011-2012$ \\
\hline & \multicolumn{4}{|c|}{ Quantity tonnes } \\
\hline India & 2836804 & 2545988 & 3081468 & 4334925 \\
\hline $\begin{array}{l}\text { Andhra Pradesh } \\
\text { (Nellore Dt.) }\end{array}$ & 1251780 & 958934 & 1132270 & 1238181 \\
\hline Production\% (Nellore Dt.) (Ave\%36.72) & 44.12 & 37.66 & 36.55 & 28.56 \\
\hline
\end{tabular}

\subsection{Resources}

Exploration and exploitation of Nellore silica sand is rather easy owing to its occurrence at surface without any overburden with scope to determine its quality and reserves with ease. All of the sand resources will require some form of processing to upgrade them into marketable form. A critical factor, therefore, in defining a sand deposit as a silica sand resource is its inherent particle size and the ease with which impurities can be removed together with the level of losses incurred in this process. Surface areas of prospective areas both with vegetation and devoid of vegetation are calculated using ArcGIS software (Fig.4). The common scantily distributed cashew-nut vegetation needs to be scraped off for mining in prospective areas covered with vegetation. Also two reserve forests (RF) exist in the area, viz., Momidi RF east of Momidi village and 
Kottapatnam RF on the east of Buckingham Canal. Prospective areas falling within these RF areas need to obtain clearance from ministry of environment $\&$ forests while proceeding for a prospecting or mining lease.

The resource estimation is based on thickness, which has been encountered in the auger hole sections and also on excavated sections in active mines. Out of total 10 meter thick layer, resources are calculated for the sand column of 8 meters thickness only considering wastage caused by discarding surface sandy silt, black sand and coarse iron rich sand, which is considered as $20 \%$ of the total volume. Resources are calculated by estimating the volume of the area multiplied by specific gravity (1.54). Due to the exigencies of occurrence of water table at shallow depth, hindering further excavation, local miners are forced to move to other area for excavation, after reaching a depth of 1-2 meters and only this depth is considered for calculating resources. A technological advance in washing, processing and beneficiation technology needs to be developed to reduce iron content, hence at the current juncture, thickness of 8 meters can be considered for estimating resources of silica sand. From the above, it can be inferred that about 849 Million Tons reserve of silica sand is prospective. In Chintavaram area, black sand occurs at $\sim 6$ meters depth and is followed by coarse iron rich sand that is unsuitable for glass making up to a depth of 21 meters which is revealed in deepest excavation in one of the mines. Estimated resources of silica sand deposit in the study area is given in Table 6.

Table 6. Elements delineated from Google Earth image and Tonnage of silica sand in the study area for depth range up to $8 \mathrm{~m}$.

\begin{tabular}{|c|c|c|c|c|c|}
\hline \multicolumn{2}{|c|}{ Feature } & \multicolumn{2}{|r|}{ Area (Sq.Km) } & \multirow{2}{*}{$\begin{array}{l}\text { Volume }\left(\mathbf{S q} \cdot \mathbf{m}^{\mathbf{3}}\right) \\
76304000\end{array}$} & \multirow{2}{*}{$\begin{array}{c}\begin{array}{c}\text { Quantity } \\
\text { (Million Tons) }\end{array} \\
117^{*}\end{array}$} \\
\hline \multirow{2}{*}{\multicolumn{2}{|c|}{ 1. Active mining area (Currently operated) }} & \multirow[t]{2}{*}{14.343} & Already mined 9.53 & & \\
\hline & & & Available for mining 4.805 & 38440000 & 59 \\
\hline \multirow{2}{*}{ 2. Prospective area } & with vegetation & \multicolumn{2}{|l|}{35.204} & 281632000 & 433 \\
\hline & without vegetation & \multicolumn{2}{|l|}{33.935} & 270680000 & 416 \\
\hline \multicolumn{5}{|c|}{ Total resources available (* excluded) } & 908 \\
\hline
\end{tabular}

Chemically the field and laboratory data shows that sands of Momidi area contain high $\mathrm{Fe}_{2} \mathrm{O}_{3}(2100$ ppm) and Ballavolu sands are observed to be containing lowest amount of $\mathrm{Fe}_{2} \mathrm{O}_{3}(200 \mathrm{ppm})$ in the entire area, whereas Chintavaram sands fall in between this. From the present study, it is inferred that about 117 Million Tons of silica sand covering $9.53 \mathrm{Sq} . \mathrm{Km}$ has already mined to the possible depth until which washable sand is excavated and still about 59 Million Tons of sand is available for mining in currently active mine sites. Further 849 Million Tons of silica sand can be prospected w.r.t industry requirements over an area of $70 \mathrm{Sq} . \mathrm{Km}$ (Table $6)$.

\section{Conclusion}

Though about 117 Million Tons of silica sand has been mined approximately for the last one to two decades, from this study it is estimated that about 59 Million Tons is still available in active mines and 849 Million Tons of prospective good quality sand resources covering an area of $69 \mathrm{Sq} . \mathrm{Km}$. is present. Out of the available prospective resources, 416 Million Tons are covered with scanty vegetation and/or reserved forest which needs to be excavated in an eco-friendly manner.

\section{Acknowledgements}

Thanks are due to Mr. V. Krishnamohan, Mr. D. Umasankar and Mr. A. Venu for providing man power, infrastructure and software. Mr. T. Jayaram and Mrs. U. Jyothy, and Mr. NVN Suresh, geologists are thanked for technical assistance and Mr. G. Chandrasekhar for GIS work. Mr. Y. Ashok Kumar, Geologist, Gudur is personally acknowledged for fruitful discussions. Technical experience gained by the author at Saint Gobain India Ltd., during 2007-2008 is gratefully acknowledged and used as a knowledge base in carrying out this work.

\section{References}

[1]. Ayyavaraiah, T, Ramanaiah, S. and Jagadiswara Rao, R, Conflicts in the Use of Dune Sands in the Coastal Zone between the Kandaleru and Swarnamukhi Rivers of Nellore District, Andhra Pradesh, India, Open Access e-Journal Earth Science Indiawww.earthscienceindia.info Popular Issue, VI (II), 2013, 1-8.

[2]. IS:488-1980, Bureau of Indian Standards,. IS specification for glass making sands, Indian Standard Institution, New Delhi, 1980.

[3]. IBM, Quartz \& silica sand: Bull. No. 25, Training, Mining Research \& Publication Division, Indian Bureau of Mines, Nagpur, $1993,96 \mathrm{p}$.

[4]. IBM (2011a) Extract from monthly statistics of mineral production February 2011 issue: 5 p. http://ibm.nic.in/avgvalueall_feb11.pdf

[5]. IBM (2011b) Quartz \& Other Silica Minerals (Advance Release), Indian Minerals Yearbook 2011 (Part- II), 50th Edition. http://ibm.gov.in/IMYB\%202011 Quartz.pdf 
Evaluation of glass-grade silica sand resources, Nellore District, Andhra Pradesh, India using GIS.

[6]. IBM (2012), Bulletin of Mining Leases \& prospecting Leases, (Excluding Atomic Minerals, Coal, Lignite, Petroleum, Natural Gas and Minor Minerals), Ministry of Mines Prepared by Mineral Economics Division, 2012 89pp.

[7]. IBM (2013), Statistical Profiles Of Minerals 2012-13 Issued by Controller General, Indian Bureau of Mines, Nagpur, October 2012 Chief Editor A. K. Singh. 